\title{
TAF1L wt Allele
}

National Cancer Institute

\section{Source}

National Cancer Institute. TAF1L wt Allele. NCI Thesaurus. Code C150334.

Human TAF1L wild-type allele is located in the vicinity of 9p21.1 and is approximately $6 \mathrm{~kb}$ in length. This allele, which encodes transcription initiation factor TFIID subunit 1-like protein, is involved in the modulation of transcription during male meiosis. 